\title{
Grundtvigs forfatterskab i dansk litteraturhistorieskrivning
}

\section{Af Per Dahl}

Artiklen gennemgår Grundtvig-billedet $\mathrm{i}$ de centrale danske litteraturhistorier fra 1881 til 2008. Vilhelm Andersens fremstilling fra 1924 ses som den vigtigste, idet den etablerede en nybrydende, littercer forståelseshorisont, hvis greb og kanondannelse analyseres. Dens indflydelse kortlægges i efterfølgende litteraturhistorier, hvis samspil med løbende Grundtvigforskning punktvis tages op. Endelig diskuteres en række forhold vedrørende litteraturhistoriografi, udgivelse og kanondannelse. ${ }^{\text {' }}$

Store fremstillinger af Danmarks historie udgives med relativt korte mellemrum, ofte ledsaget af en livlig og kontant diskussion af metodiske problemer og faglige vurderinger. Ved hver udgivelse făr historikere af samme generation lejlighed til at forholde sig til hinanden, begrunde deres metodiske ståsteder og holde kritikken skarp.

Danske litteraturhistorier udsendes med noget større mellemrum. Ligesom salmebøgerne holder de ofte et halvt århundrede, før de bliver fornyet, og ved præsentationen samler den umiddelbare interesse sig derfor hyppigt om den relativt lange række af nye forfattere, der nu bliver skrevet i mandtal, måske endda kanoniserede. Eventuelle omvurderinger i det ældre stof påkalder sig ikke nær samme interesse, og samtidig fortoner den faglige diskussion af metodiske problemer sig blandt de forskere, der befinder sig på en generations afstand eller mere i forhold til hinanden. Litteraturhistorier er så langtidsholdbare, at deres fædre lider strådøden!

En dansk litteraturhistorie er (ifølge Conrad 1996) en fortællende, kronologisk ordnet fremstilling af dansk litteratur fra begyndelsen til nu. Til hvert eneste af definitionens led er der knyttet grundlæggende afgrænsningsproblemer. For eksempel kan “dansk" være en sproglig, en kulturel eller en geografisk afgrænsning, og "litteratur" er et vidt begreb, der har ændret indhold fra 1700-tallets brede lærdomsforestillinger til det snævre begreb om skønlitteratur, vi uden videre opererer med i dag, men som først blev fastlagt hen imod år 1900.

Artiklen er en bearbejdet og udvidet version af et foredrag, holdt $\mathrm{i}$ Vartov 3.11.2007 som led i en seminarrække om "N. F. S. Grundtvigs skrifter - deres virkningshistorie og deres betydning i dag". Tak til Aage Jørgensen og Johnny Kondrup for beredvilligt, kritisk gennemsyn. 
Historiske kilder har sjældent selvstændig værdi; vi læser dem ikke for deres egen skyld, men først og fremmest for de informationer, de kaster af sig. Selv over stor tidsmæssig afstand er vi derimod i stand til at have umiddelbar glæde af litterære tekster som æstetisk og følelsesmæssigt virkningsfulde helheder.

Hvordan forholder det sig på det punkt med hensyn til Grundtvigs vidtstrakte forfatterskab? Hvilke dele af det skønnes i dag at have litterær værdi og hører således fortsat til skønlitteraturen og dermed litteraturhistorien? Og hvilke dele tages alene op i bredere fremstillinger af for eksempel dansk kirkehistorie, oplysningshistorie og politisk historie? Her stikker spørgsmålet om litterær kanondannelse frem.

Da Vilhelm Andersen i 1931 i Det Kongelige Danske Videnskabernes Selskab gjorde rede for de to store bind litteraturhistorie om det 19. århundrede, han efter 10 års arbejde netop havde afsluttet, henledte han selv opmærksomheden på de indre spændinger i værket:

det forelagte Værk [svarer] kun lidet til det gængse Begreb af en Litteraturhistorie. Dertil er der for lidt Historie og for meget Litteratur deri. Det første er givet med Grundsynet i Personligheden og ikke Samfundet som Basis for Opfattelse og Fremstilling. Det andet mærkes baade kvantitativt og kvalitativt. Der er efter den almindelige Opfattelse taget for meget med. I Redegørelsen for det enkelte Forfatterskab staar Fejlgrebene ved Siden af Mesterværkerne som lige nødvendige for Forstaaelsen af det hele; (Andersen 1985, 98).

$\mathrm{Da}$ det er personligheden og ikke den brede, historisk udfoldede samfundsbeskrivelse, der udgør fremstillingens grundlag, bliver forfatterskabet den fremstillingsform, der bedst integrerer de udforskede detaljer. Og da det tillige er forståelsen af personligheden i dens udvikling og sammenhæng, der står i centrum, tages alt, hvad der tjener dette formål, med og spænder sig op imod rent æstetiske vurderingskriterier. Skønt fremstillingen præsenterer sig som en sncever litteraturhistorie, er dens litteraturbegreb på sin vis dog rummeligt.

Når en karakteristisk måde at skrive på kan identificeres i en række tekster af samme forfatter, bliver 'forfatterskab' nærliggende som dispositionelt greb i den litteraturhistoriske fremstilling, måske med karakter af biografisk portræt. Beskrives for eksempel et århundredes forfatterskaber sådan, som Vilhelm Andersen gør det, ét efter ét og ordnet i tiår efter debuten, kan det imidlertid blive vanskeligt at fastholde historisk sammenhæng og samtidighed i fremstillingen.

Kronologisk ordning (periodisering) kan foretages på mange måder. Opfatter man det 19. århundrede som delt i flere perioder, hvordan skal Grundtvigs næsten 70 år lange forfatterskab så distri- 
bueres? Og hvis man iagttager skel eller gennembrud i hans liv og værk, skal de så søges samordnet med historiens milepæle?

Flemming Conrad har gjort opmærksom på (Conrad 2006), at den faste kanon af store og små poeter fra perioden 1800-1870 blev etableret allerede i perioden selv. Den har i tidens løb holdt sig uanfægtet og genfindes stort set uændret i den 'lille kanon', som undervisningsministeriet i 1994 bad gymnasierne rette ind efter. Over for en sådan stabilitet kan det synes formålsløst at tage den behandling, Grundtvigs forfatterskab blev til del i de skiftende litteraturhistorier, frem til fornyet eksamination.

Når forsøget ikke desto mindre er gjort, og nogle resultater her fremlægges, er det, fordi fremstillingerne af netop Grundtvigs forfatterskab i højere grad, end man umiddelbart kunne have forventet, byder på perspektivskift og ændrede vurderinger, og fordi en hel række af de netop skitserede udfordringer ved at skrive litteraturhistorie her i så høj grad viser sig at være til stede og blive besvaret på vidt forskellige måder.

Grundlaget er ni store, danske litteraturhistorier mellem $1881 \mathrm{og}$ 2008. Der findes naturligvis mange flere, heriblandt også tysk- og engelsksprogede, men jeg har skønnet, at de udvalgte står så centralt, at en hovedlinje har kunnet fastlægges, og at yderligere dokumentation blot ville føre til kvantitativ ophobning og en unødigt lang artikel. ${ }^{2}$

\section{Den danske Literaturs Historie (Frederik Winkel Horn)}

Frederik Winkel Horn (1845-98) var magister i nordisk oldtidsvidenskab og siden doktor på en afhandling om Peder Syv, men opnåede aldrig ansættelse ved Københavns Universitet. Ved siden af de ansættelser, han havde inden for folkeoplysende arbejde, virkede han som oversætter og populærvidenskabelig skribent. Blandt hans alment tilgængelige værker var Den danske Literaturs Historie, et værk på godt 800 sider, der udkom heftevis $1879-81$, fordelt på to bind. Det er den første større fremstilling, der også behandler dansk litteratur i det nittende århundrede, nemlig "fra dens Begyndelse til vore Dage", som det hedder på titelbladet, og det vil sige frem til

2 Uden for danske litteraturhistorier i snævrere forstand findes der fyldige, litterære Grundtvig-portrætter, således i Vilhelm Østergaards Illustreret dansk Literaturhistorie (1907); undertitlen, "Danske Digtere i det 19de Aarhundrede", antyder dog værkets karakter af enkeltstående portrætter. Noget lignende kan siges at gælde de meget fyldige portrætter i Det Danske Sprog- og Litteraturselskabs digitale Arkiv for dansk litteratur (ADL), som er tilgængeligt via selskabets og Det Kongelige Biblioteks hjemmesider. ADLs Grundtvig-portræt er forfattet af Flemming Lundgreen-Nielsen. 
affattelsestidspunktet i snævreste forstand. Georg Brandes' essay om "Goethe og Danmark", der er en af de nyeste tekster, der omtales i værket, udkom i marts 1881, så Horn har været endog meget up to date. Hans litteraturhistorie blev efterfulgt af en bog om N.F.S. Grundtvigs Liv og Gjerning, 1883. Dermed er antydet en positiv grundholdning over for forfatterskabet, der her fik sin første, fyldige og overskuelige behandling i en litteraturhistorie.

Det velorienterede kapitel om Grundtvig (Winkel Horn 1881, 189234), eller "Præsteskjalden", som han benævnes i indledningen, er fortællende og refererende, men dokumenterer også ved hjælp af flere store citater. Bortset fra nogle sammenlignende linjer om forståelsen af nordisk oldtid i det umiddelbart foregående afsnit om Oehlenschläger (134) lukker kapitlet sig i høj grad om sig selv, idet Grundtvigs ideer om en særlig nordisk-kristelig dannelse står i centrum, både i den løbende fremstilling og på de ca. 10 sider, der ved vejs ende gør status. Efter at Grundtvigs ideer her har fået deres, fremhæves det levende ords betydning for troen (i modsætning til læren, den teologiske dogmatik), og hans katekismus sammenfattes i de tre paragraffer, at "1) Aand er Magt; 2) Aand aabenbarer sig kun i Ordet; [3] Aand virker kun i Frihed" (Winkel Horn 1881, 232). ${ }^{3}$

Til sidst karakteriseres Grundtvig som en kunstner af særlig karakter. Hans værker er båret af ideer:

Derfor er det ogsaa saa godt som udelukkende religiøse og historiske, særlig nordisk-historiske Æmner, han behandler, og derfor bærer saa meget af hans Digtning Improvisationens Præg, hvilket den i æsthetisk Henseende skylder saa vel sine Fortrin som sine Mangler. (...) her er ikke Tale om nogen af kunstneriske Hensyn betinget Vragen og Vælgen af Udtryk. (...) Følgen heraf bliver, at der ofte i det selv samme Digt ved Siden af den højeste Skjønhed kan træffes Udtryk, der støde som platte og smagløse og skurre imod den Tone, der i det hele anslaas, og at Tanken ofte er saa uklart udtrykt, at det bliver vanskeligt for Læseren at faa sikkert fat paa den. Det er forholdsvis faa af Grundtvigs mange Digte, der kunne siges at være fuldstændigt pletfri i saa Henseende (...) Hans Digtning er gjennemgaaende præget af en sjælden Kraft og Inderlighed; man føler bestandig, at den udstrømmer fra en stærkt bevæget, dybt poetisk Aand; hans Ord komme altid fra Hjærtet og gaa til Hjærtet (Winkel Horn 1881, 233-234).

Her, på digtningens område, hvor det er relevant at stille kunstneriske krav, fremføres de æstetiske indvendinger, der kan gøres gældende mod værkernes form - og de indrømmes plads. Men kritikken skydes dog til side under henvisning til værkernes kraft (et (præ-)romantisk

3 Winkel Horn foretager sin sammenfatning på anonym anden hånd; muligvis Frederik Barfod? 
kerneord) og den inderlighed eller det liv, der strømmer direkte fra hjerte til hjerte og gør akademiske formbetragtninger irrelevante. Det sidste er en meget tidlig variant af en vitalistisk oplevelsesæstetik, som senere bliver bragt til udfoldelse hos blandt andet Vilhelm Andersen. Her består der netop kongruens eller lighed mellem tilblivelse og tilegnelse, mellem produktion og reception: Processerne forstås i og med det samme begreb.

Også prosaen, viser det sig efterfølgende, besidder imidlertid de fordele og ulemper, der præger Grundtvigs digtning; også her bortviftes ulemperne og vendes til en fordel:

Den kan synke helt ned i det platte, men bestandig er den i højeste Grad livfuld og overrasker jævnlig ved i høj Grad slaaende, karakteristiske Udtryk og Vendinger. Den har mere af den aandfulde Mands dagligdags mundtlige Foredrag end af Skriftsprogets sædvanlige Karakter. Grundtvig er ogsaa i sin Stil, hvad enten han skriver Vers eller Prosa, det levende Ords Mand (Winkel Horn 1881, 234).

Formelle indvendinger mod Grundtvigs prosa, betragtet som kunstneriske helheder, synes ikke at have vejet tungt, hverken for Winkel Horn eller hans samtidige. Tilegnelse af meningen i Grundtvigs ord, der måske ofte fandt sted i kombination med en formidling på anden hånd, har været det afgørende.

I en vis udstrækning har det samme forhold formentlig også gjort sig gældende under læsning og brug af Grundtvigs digte og salmer. Den ofte hårdhændede redigering af teksterne har næppe stået $i$ vejen for tilegnelsen af meningen, snarere tværtimod. En kortlægning af det tekstmæssige grundlag for Grundtvig-receptionen og af Grundtvigantologiseringen i de skiftende udgaver af højskolesangbogen, salmebogen og for eksempel højskolernes og gymnasiets litteraturudvalg ligger imidlertid uden for denne artikels ramme.

\section{Illustreret dansk Litteraturhistorie (P. Hansen)}

Peter Hansen (1840-1905) afsluttede aldrig sine litterære og æstetiske studier. Efter accessit 1863 for den prisopgave om den tragiske skæbne, som også Georg Brandes besvarede og fik guldmedalje for, gled han ind i journalistik og redaktionelt arbejde. Hans Illustreret dansk Litteraturhistorie udkom i hefter 1883-86 (jf. den udførlige fremstilling i Conrad 2006, 155-181). Det var den første illustrerede, danske litteraturhistorie, og såvel brødtekstens layout med fremhævelser og marginalt placerede nøgleord som præsentationen af de mange tekstprøver og facsimiler gjorde den igennem en årrække til markedets bedste håndbog, genudgivet 1895-1902. 
Værkets behandling af "Det nittende Aarhundrede" opererede med en klar periodedeling: 1800-1825 ("Idealismens Frembrud og Sejr"), 1825-50 ("Realismen i Pagt med Idealismen") og 1850-70 ("Periodens Afslutning"). Grundtvig og hans forfatterskab blev derfor behandlet flere steder: (a) tiden frem til 1813 (324-335), (b) striden med Jens Baggesen (350-351; 359-361), (c) fra 1813 til 1825 (367-372), og (d) fra 1827 til ca. 1848 (525-533). Flemming Conrad peger på, at Peter Hansens fortællende træk omfattede anskuelighed via anekdoter og situationer $\mathrm{og}$ en tendens til at fastholde forfatter og forfatterskab som bærende kompositorisk element. På grund af faserne i periodiseringen bestod en udfordring for hans kunst som fortæller derfor " $i$ at synliggøre flest mulige fælles knudepunkter for flest mulige individuelle 'tråde"' (Conrad 2006, 173-174).

De litterære afsnit om Grundtvig adskiller sig fra Winkel Horns medlevende skildring. Peter Hansens æstetiske vurderingskriterier var Heiberg-skolens krav om klarhed og naturlighed. Da Grundtvig i 1813 kom tilbage fra Udby, var hans gærende indre så stærkt bevæget, at "Udtryk og Form hyppigt blev dunkel og gaadefuld" (Hansen 1886, 367), ligesom tidsskriftet Danne-Virke bliver "Organ for den exklusive Danskhed, den hyperpatriotiske Folkeforgudelse, som Grundtvig alt tidligere havde gjort sig til Tolk for" (368). Om oversættelserne af Snorre og Saxo (1815-22) siges det, at de er enestående ved fortællingens jævnhed og fynd, men også vækker mistanken om, "at han ikke altid vilde formaa at holde denne sin Bestræbelse paa den rette Side af Smagsgrændsen. I Virkeligheden tilsidesættes ogsaa jevnlig Foredragets Værdighed for Stilens grovere Virkninger, og saavel Plathed som Bizarreri skæmmer nu og da den historiske Tone" (369). Tidligere i værket (bind 1, 17-21) havde Peter Hansen sammenstillet et stykke af Saxos latinske tekst og Anders Sørensen Vedels oversættelse; pædagogisk føjes nu det tilsvarende stykke i Grundtvigs oversættelse til som belæg for udsagnet.

$\mathrm{Da}$ fremstillingen $\mathrm{i}$ overensstemmelse med periodedelingen genoptages (525-533), gælder den udelukkende Grundtvigs rent digteriske produktion. Krønike-Rim (1829) fremhæves for smeltende sødme og gribende humor, mens Sang-Vark (1837-41) udløser uforbeholden ros. Grundtvig er som salmist "den frugtbareste og den ypperste danske Digter i dette Aarhundrede, Kingos Jevnbyrdige og Aandsfælle" (529). Hans stærke personligheds præg er ikke alene fuldt til stede $\mathrm{i}$ de originale salmer, også hans gendigtninger har "modtaget umiskjendelige Mærker af hans Digteraands Ejendommelighed, saavel dens kraftige Bevægethed, dens selvstændige Udtryksmaade som dens ikke altid ganske sikre Smag" (530). 
Peter Hansens varme roser savnede aldrig smagfulde torne. Hedenskabets fyndstil kan i salmerne anvendes "kjønt og naturligt", men "paa andre Steder kan Jargon'en fra en mindre ædel Forestillingskreds virke som en Smagsforsyndelse ved sin grelle Forbindelse med det høje Emne" (530).

Sublim prægnans i udtrykket findes sammen med "en indtil Uforstaaelighed sammenskruet Billedmasse", og læseren spares ikke for plebejiske rim som "Æble" og "Djævle". Peter Hansens karakteristik af Grundtvigs salmedigtning løfter sig imidlertid ikke fra de her anførte, ambivalente og punktuelle nedslag til nogen mere indgående redegørelse.

Sidste fjerdedel af afsnittet om det 19. århundrede i Illustreret dansk Litteraturhistorie er en beskrivelse af videnskaberne, forfattet af fagfolk. Her er der endnu to omtaler af Grundtvigs forfatterskab (629630; 641-652), idet filosoffen Harald Høffding (1843-1931) skriver om filosofi og professor og senere biskop H. V. Sthyr (1838-1905) om teologi.

Den politisk konservative H. V. Sthyrs behandling fremtræder (i det mindste for en ikke-teolog) som en forholdsvis nøgtern redegørelse for Grundtvigs teologiske og kirkelige standpunkter. Den kan eventuelt sammenholdes med Frederik Nielsens Grundtvig-portræt i første udgave af Dansk biografisk Lexikon (1892, bind 6).

Derimod er Harald Høffdings sammenfatning om Grundtvig ganske skarp:

Hans Begreb om Videnskab vedblev saavelsom hans Livsanskuelse at bære Romantikkens Præg. De aandelige Syner med deres Genialitet og deres Vildfarelse vare hos ham altid stærkere end den prøvende Kritik. Sandsen for Fænomenernes ideale Betydning forenedes ikke med Interesse for deres reale Sammenhæng. Heri ligger Begrændsningen for den store Mands i og for sig saa frugtbare og gavnlige Indflydelse paa vort Folks Aandsliv, en Begrændsning, der for en Del skyldes den Tid, indenfor hvilken hans Læreaar faldt (Hansen 1886, 630).

Overordnet set er behandlingen af Grundtvig i Peter Hansens litteraturhistorie således fanget $\mathrm{i}$ en distancerende klemme mellem på den ene side traditionen fra en lidt ældre, heibergsk smags- og formæstetik og på den anden side Høffdings afvisning af Grundtvigs tankeverden ud fra et moderne, positivistisk standpunkt.

\section{Illustreret dansk Litteraturhistorie (Vilhelm Andersen)}

Fra 1908 til 1930 var Vilhelm Andersen (1864-1953) professor i dansk og nordisk litteratur ved Københavns Universitet. I årene fra 1921 til 1934 udgav han bind 2, 3 og 4 af Illustreret dansk Litteraturhistorie, 
der fra forlagets side oprindelig var tænkt som en ny og tredje udgave af Peter Hansens værk. ${ }^{4}$ Bind 3 og 4 omhandlede litteraturen fra ca. 1800 til ca. 1900, og de udkom først, da det efter forfatterens vurdering var de bind, der var mest brug for. N. M. Petersens litteraturhistorie (1853-61, 2. udg. 1867-72), der var den nærmeste, universitcere forgænger, havde nemlig kun ført sin fremstilling frem til ca. 1800 , og der var brug for at få indskrevet det nittende århundredes første og især dets anden halvdel, herunder det moderne gennembrud, $\mathrm{i}$ en litteraturhistorisk fremstilling og helhedsopfattelse. Winkel Horns og Peter Hansens litteraturhistorier, der førte frem til ca. $1880 \mathrm{og}$ ca. 1870 , gjaldt for populære værker.

Bind 3 (141-217), der behandler Grundtvigs forfatterskab, udkom som de øvrige bind i hefter og forelå afsluttet i 1924. Som for andre af kapitlerne gælder det ikke mindst for Grundtvig-fremstillingen, at den er indforstået og vanskelig at læse og derfor tager tid at tilegne sig. De 75 sider er - i enhver forstand - tæt skrevne; de er ikke opdelt i mindre afsnit, og de savner helt rubrikoverskrifter. Det er der ganske vist ikke noget usædvanligt $i$, for det gælder samtlige forfatterkapitler $i$ Illustreret dansk Litteraturhistorie. Derfor tilegnes de bedst 'i ét sæde'.

Ikke desto mindre gav Vilhelm Andersens komprimerede kapitel det indtil da bedste, samlede Grundtvig-portræt. Det skyldes flere forhold. For det første hans førstehåndskendskab til alle forfatterskabets væsentligste skrifter. For det andet at han læste forfatterskabet som en enhed og helhed. Og for det tredje at han i kraft af den litteraturhistoriske ramme, han skrev inden for, kunne anlægge et alment og litterært synspunkt på forfatterskabet og dermed holde distance til de mange brugs- og virkningshistoriske aspekter, der gjorde sig gældende inden for grundtvigianismens teologiske, organisatoriske og uddannelsesmæssige forgreninger, eller, som det hedder: "I den grundtvigske Litteratur lærer man den 'rigtige' Grundtvig at kende, bag Salmebogen og Grundtvigianismen" (Andersen 1924, 216).

Vilhelm Andersen var vokset op i et hjem, der var præget af Mynstersk kristendom (faderen var provst i Ringsted) og læsning af Holberg og guldalderlitteraturen. I sin studietid knyttede han forbindelse med teologen, den senere udenrigsminister for Venstre,

4 I efteråret 1916 påbegyndte Gyldendal en heftevis udsendelse af en tredje udgave af Peter Hansens værk, redigeret af Carl S. Petersen, men udgivelsen af bind 1 gik efterhånden i stå, og i 1919 indgik forlaget aftale med Vilhelm Andersen om at skrive bind 2, 3 og 4, begyndende med bind 3; heftet med siderne om Grundtvig udkom sandsynligvis 1921-22. Jf. indledningen til Andersen 1985, 22-24. 
Laust Moltesen (1865-1950), og omkring århundredskiftet med højskolefolk som Holger Begtrup (1859-1937) og Thomas Bredsdorff (1868-1922). Hans religiøsitet var imidlertid ikke af konfessionel karakter, hvad man blandt andet kan se af hans pseudonymt udsendte 'bekendelser', Aaret og Dagen fra 1901. Han var nemlig også et barn af det moderne gennembrud: Af Georg Brandes' forfatterskab havde han lært litterær metode, og han hørte som halvt hedning til 'jætterne'. Imidlertid ser det ud til, at han har været ganske velbelæst i Holger Begtrups små Grundtvig-bøger fra årene omkring århundredskiftet. For kapitlet i Illustreret dansk Litteraturhistorie udgør de øjensynligt Vilhelm Andersens nærmeste sekundærlitterære fundament.

Vilhelm Andersens litterære førstehåndskendskab gav sig blandt andet til kende i præcise citater og pointerige, tematiske sammenstillinger. Illustreret dansk Litteraturhistorie er således den første danske litteraturhistorie, der i sin fremstilling oparbejder og integrerer elementer af litterær analyse og dermed bringer læseren tæt på forfatterskabernes litterære højdepunkter. Enheden og helheden i Grundtvigs forfatterskab skrives frem ved at søge en indre, strukturel sammenhæng i teksterne og se dem behersket af én klar figur - den grundoplevelse, der går igen i Grundtvigs mange forskellige gennembrud (et andet nøgleord), nemlig den bevægende og bevægelige modsætning mellem død og liv, "hvor Lyset altid fødes af Mørket" (Andersen 1924, 155).

Oplevelse og gennembrud var ifølge Vilhelm Andersen forudsætninger, som Grundtvig delte med Oehlenschläger og hans 'generation'. Ganske vist havde han - ikke helt i overensstemmelse med sit eget tiårs-system - placeret Grundtvig i århundredets andet slægtled eller tiår, men der var blot fire år mellem de to forfattere, så dermed kunne Vilhelm Andersen se sin forestilling om et romantisk gennembrud $\mathrm{i}$ århundredets første år dokumenteret og bekræftet.

Fremstillingsmæssigt åbner de synkrone og kongruente gennembrud for en pædagogisk kontrastering. I modsætning til Oehlenschläger har "Grundtvig (...) ingen klassiske Værker skrevet", fastslås det i kapitlets indledning (141). Han var ingen skabende kunstner, men en avlende ånd. Over for kunstnerens plastiske billede står Grundtvigs åndelige syn: "Oehlenschlæger ser (Guldhornene, Aladdin), Grundtvig (Hadding, Nyaarsmorgen) har Syn, det er hans Geni, og han har Syner, det er hans Galskab" (Andersen 1924, 216).

De centrale tekster i Grundtvigs forfatterskab bliver for Vilhelm Andersen dels det store digt Nyaars-Morgen (1824), "der er en Myte af hans eget Liv, ligesom 'Aladdin' af Oehlenschlægers" (Andersen 1924, 168) - dels det samtidige digt, salmen "De Levendes Land": 
Dersom man af alt, hvad Grundtvig har skrevet, skulde udvælge et Blad til at give dem, der kun kender lidet til ham selv, et levende Indtryk, ligesom et Haandtryk, af ham, helt som han var - Digteren og Præsten, Manden før og efter den store "Opdagelse" - maatte det blive dette religiøse Digt, som han skrev paa Højden af sin Manddom og sin digteriske Evne (Andersen 1924, 173).

Håndtryks-metaforen er dels en varieret gentagelse af Winkel Horns hermeneutik, som den kom til udtryk i vendingen 'fra hjerte til hjerte', dels rummer den filologisk autoritet og anskueligt nærvær ved forinden at have henvist til den oprindelige version, og endelig sættes håndtrykket ind som det centrale, mest intime og sande sted i den biografiske forståelsesramme: "helt som han var". Udtrykket minder jo påfaldende om den tyske historiker Leopold von Rankes "wie es eigentlich gewesen" og rummer i sin forestilling om en selvforglemmende samtidighed med emnet den samme hermeneutiske illusion. ${ }^{5}$

Der er yderligere det raffinement, at Grundtvig før 1824 opfattes som digter, efter 1824 som præst, samlet set som 'mand'. Distinktionen kommer til at disponere Vilhelm Andersens fremstilling, jf. nedenfor. Endelig ligger der et receptions- og forskningshistorisk perspektiv, som jeg vender tilbage til i slutningen af artiklen.

For at få digtets epokale og grundtvigske træk til at træde i karakter sammenlignes det med Thomas Kingos "Far, Verden, far vel". Det er, så vidt jeg kan se, Vilhelm Andersen, der som den forste anlægger denne pædagogisk effektive sammenligning, der siden er blevet gentaget i næsten alle danske litteraturhistorier. "Far, Verden, far vel" er skrevet i samme versemål og har samme centrale placering i Kingos Aandeligt Siunge-Koor som "De Levendes Land" i Grundtvigs SangVaerk. Men de to tekster er også modstykker. Mens Kingo og hele hans lutherske tid er "stærk i Ordet som faa, naar han skal sige Verden sit Farvel", er han "maalløs i Udtrykket for Evighedens Glæde". Det er her, Grundtvig formår at give evighedens magter ord: "Troen, Haabet og Kærligheden". Også som salmedigter ses Grundtvig da som "et Barn af den store Livsfornyelse fra Aarhundredets Begyndelse, hvis Morgenstemning han har genfundet i Indgangen til Nyaarsmorgen" (Andersen 1924, 173).

5 Leopold von Ranke (1795-1886) anvendte udtrykket i forordet til sit debutværk Geschichte der romanischen und germanischen Völker 1494 bis 1534 (1824), og det har været et omdrejningspunkt i de fleste senere fremstillinger af historieskrivningens teori og metode, i Danmark siden Kristian Erslevs øvelser i historisk teknik, 1887 ff., som Vilhelm Andersen fulgte. 
Fra det højdepunkt i 1824, der etableres med udpegningen af de to centrale tekster, kan Vilhelm Andersen ubesværet trække linjer tilbage og frem i forfatterskabet:

Med "Nyaarsmorgen" og Hadding-Sagnet er "De Levendes Land" nøje forbundet allerede ved sin Titel. Det forholder sig dertil som Julesangen om de hellige tre Konger ["Dejlig er den Himmel blaa", 1810] til Digtene i "Nyaarsnat" (...) og er vel undfanget efter eller under Arbejdet paa det profetiske Kvad som Klarheden efter Gæringen, Stjernen mellem Skyerne. Og lige saa tydeligt viser det frem i Grundtvigs senere Digtning og i hans Gerning i Kirken og Folket. Man kan fremdrage nogle Digte især fra de nærmest følgende Aar, hvori Tanken fra "De Levendes Land" er ført ud i de Krese af det praktiske Liv, hvori han nu skulde virke. For praktisk er Grundtvigs nye "Gennembrud" i Modsætning til de tidligere: det poetiske, det kristelige, det historiske. (...) Aaret 1824 med "Nyaarsmorgen" og "De Levendes Land", Grundtvigs fyrretyvende Leveaar, bliver da naturligvis ogsaa Højde- og Vendepunktet i Fremstillingen af hans Gerning. Den [dvs. Vilhelm Andersens egen fremstilling] har hidtil med Traaden i hans Liv fulgt de Stadier af hans Udvikling, han maatte igennem for at komme til Klarhed, men maa nu slippe den biografiske Traad for at give et samlet Billede af hvad han ud fra denne Klarhed har virket i Litteraturen i de to Hovedretninger: Kirken og Skolen eller Folket (Andersen 1924, 174).

Efter at have skrevet Grundtvigs personlige oplevelser ind i det romantiske gennembrud kan Vilhelm Andersen efterfølgende placere hans produktion som et bidrag til den poetiske realisme, der med blandt andet Poul Møllers forfatterskab og Blichers novelledebut som markører fik sit gennembrud i netop 1824. Konstruktionen rummer en uudtalt indsigelse mod at gøre Georg Brandes og den moderne realisme til dét centrale gennembrud $\mathrm{i}$ det 19 . århundrede. Ved at fremhæve tilstedeværelsen af en langt tidligere, nationalt og folkeligt funderet realisme tager Vilhelm Andersen luften ud af denne 'europæiske' konstruktion.

Kronologisk og biografisk lægger Vilhelm Andersen et snit i 182425, akkurat hvor Peter Hansen af andre grunde lagde $\sin$ periodedeling. Men hvor Peter Hansen dermed selv slap fremstillingen og overlod den til Sthyr, renoncerer Vilhelm Andersen alene på den biografiske og litterære tråd til fordel for et andet, samlet billede af Grundtvigs virke, som han selv giver.

Pointen synes at være, at Vilhelm Andersen med sin litterære og biografiske synsmåde bedre end på nogen anden måde har kunnet følge stadierne og motiverne i Grundtvigs (digterens) indre udvikling frem til dens højdepunkt og klarhed i 1824 . Perioden efter 1824 forstås da som klarhedens realisation i Grundtvigs virke (som præst); her kan 
den biografiske tråd slippes, dels fordi det - groft taget - må være Vilhelm Andersens opfattelse, at den indre udvikling for så vidt hører op eller bliver mindre interessant, dels fordi realisationen netop bedst gengives i en fremstilling af Grundtvigs omsætning af motiverne i ydre virke. 1824 bliver "Højde- og Vendepunktet".

Det er et meget karakteristisk træk i Vilhelm Andersens metode, at han viser den indre, menneskelige udvikling og motivation bag et ydre brud eller skifte. Han afleder bruddet indefra og lader dets menneskelige og litterære betydning supplere eller ligefrem overskygge ydre skel eller ideologiske fronter. I sine refleksioner ved fremlæggelsen af de to bind om det 19. århundrede bestemte han selv denne metode som induktiv.

Og dog har dette metodiske træk sin konforme grænse: Som hovedregel viser dens resultater sammenfald med den litterære traditions opfattelse af det litteraturhistoriske forløb og dets cæsurer.

I forbindelse med Grundtvigs 'gennembrud' i 1824 er der yderligere to vigtige receptionshistoriske iagttagelser at inddrage. Den ene vedrører det selvbiografiske langdigt Nyaars-Morgen, den anden digtet "De Levendes Land".

Vilhelm Andersen gør selv (172) opmærksom på, at han er den første litteraturhistoriker, der - med hundrede års forsinkelse - giver Nyaars-Morgen en helt central placering. Det skyldes frem for alt to bidrag af Holger Begtrup.

Det ene er hans fyldigt kommenterede udgave af Nyaars-Morgen fra 1901, som stort set alle læsere siden har støttet sig til. Ud over en indledning rummer udgaven et tillæg, der gør rede for forarbejderne til digtet og desuden trykker en variant af fortalen samt et fyldigt uddrag af de "Glarøjne", Grundtvig selv skrev som en form for kommentar. I sin kommentar på foden af tekstsiderne udnyttede Begtrup løbende det i øvrigt utrykte Grundtvig-manuskript. ${ }^{6}$

6 Indledningen i Grundtvig 1901, 7-16, tillægget 203-27. Svend Grundtvig havde i sin udgave af faderens Poetiske Skrifter (bind 5, 1883, 153-273) optrykt førsteudgavens tekst og nummereret de ti afsnit med romertal og de 312 strofer med løbende arabertal; desuden gengav han enkelte hele strofer fra Grundtvigs udkast. Begtrups udgave fra 1901 blev i 1906 løftet over i Grundtvigs Skrifter i Udvalg, bind 4, hvor Nyaarsmorgen er optrykt s. 237343; dog er uddraget af "Glar-Øine" og udnyttelsen heraf i noterne her erstattet af en oversigt foran hvert af digtets afsnit, suppleret af enkelte fodnoter. Georg Christensen og Hal Kochs optryk i Varker i Udvalg (bind 7, 1941, 366-480) hævder at støtte sig helt til Begtrups udgave fra 1901; det ser imidlertid ud til, at det er udgaven fra 1906, der danner forlæg. 
Det andet er bogen N. F. S. Grundtvigs kirkelige Syn 1825. En historisk Indledning fra (tidligere i) 1901, som Vilhelm Andersen refererer til og - indirekte - også fra, skønt han ikke anfører titlen. Begtrups bog placerer Nyaars-Morgen som dén centrale tekst i gennembruddet og er således det faglige forarbejde og motivationen bag hans genudgivelse af teksten. Forudsætningerne for gennembruddet kortlægges i kapitel 3 via en gennemgang af prædikener fra 1823-24, mens det centrale kapitel 4 (Begtrup 1901, 64-100) er en gennemgang af teksten. ${ }^{7}$

Imidlertid følger Vilhelm Andersen ikke helt Begtrups udelte begejstring. Han er enig med ham i, at digtet er "kun fuldt forstaaeligt for dem, der er helt fortrolige med hans indre Udvikling" (Andersen 1924, 172). Med et oplysende udtryk af T. S. Eliot, som nykritikken tog op, kan man sige, at teksten savner tilstrækkeligt objektivt korrelat for digterens følelser, eller at den kunstneriske realisation ikke fuldt ud er lykkedes. ${ }^{8}$

Vilhelm Andersen driver synspunktet videre og lægger med en æstetisk vurdering en dæmper på Begtrups begejstring:

Men det er urimeligt at hæve dette Digt, hvis poetiske Flugt tynges af det litterær-biografiske Stof, og i hvis Stil store Syner omveksler med platte Ordspil til "Vølvespaas" eller blot til "Guldhornenes" kunstneriske Højde. Grundtvigs Genius er som en af de Engle, Joakim Skovgaard har malet $\mathrm{i}$ hans Aand, der har stærke Vinger og flade Fødder (Andersen 1924, 172).

Det er et af de meget fă steder, hvor Vilhelm Andersen lufter en kritik af Grundtvig, der ligger i forlængelse af Peter Hansens og den heibergske skoles smagsdomme.

Den anden iagttagelse drejer sig om "De Levendes Land", der løftes over Nyaars-Morgen. Vilhelm Andersen er øjensynlig (også her) den første, der henter manuskriptet til digtets første version fra 1824 frem fra Svend Grundtvigs udgave af Poetiske Skrifter (bind 5, 1883) og - som det lange citat ovenfor viste - giver det en helt central placering sammen med Nyaars-Morgen. ${ }^{9}$

Vilhelm Andersen nævner (Andersen 1924, 172) to afhandlinger om Nyaars-Morgen af J. H. Monrad og A. D. Jørgensen (begge fra 1896, men i den rækkefølge: A. D. Jørgensen var bekendt med Monrads lille bog). De behandles i den lange note til Begtrup 1901, 69. Auken 2005 synes helt at overse både A. D. Jørgensens fine afhandling og Begtrups grundlæggende bog.

Udtrykket blev i dansk sammenhæng introduceret af Johan Fjord Jensen i Den ny kritik, 1962, 94-95.

9 Manuskriptet blev første gang trykt i Poetiske Skrifter bind 5, 1883, 283286, af Svend Grundtvig dateret "1824"; det er optrykt Sang-Vark III, 145- 
Hvor Nyaars-Morgen for det første har en - om end mager receptionshistorie fra sin udgivelse i $1824 \mathrm{og}$, for det andet, indleder sin sene virkningshistorie fra og med Holger Begtrups to indsatser i $1901 \mathrm{og}$, for det tredje, litteraturhistorisk sét først for alvor placeres centralt med Vilhelm Andersens helhedsforståelse godt tyve år senere, så løftes "De Levendes Land" først ind i den grundtvigske teksthistorie 60 år efter sin tilblivelse og indleder sin virkningshistorie yderligere 40 år senere, da Vilhelm Andersen får øje for det. Fra da af bliver digtet en helt central tekst, der har udløst en lang række fortolkninger. ${ }^{10}$

Med sin litteraturhistoriske fremstilling dementerede Vilhelm Andersen ikke den almindelige opfattelse af 1824-25 som et omdrejningspunkt i forfatterskabet. Men hvor Grundtvigs disciple og senere teologer med Kirkens Gienmoele (1825) lagde vægten på "den mageløse opdagelse" af trosbekendelsen og udviklingen af den kirkelige anskuelse, hæftede Vilhelm Andersen sig ved det forudgående, digteriske gennembrud. Han fulgte stadierne i Grundtvigs indre udvikling frem til $1825 \mathrm{og}$ gjorde et stort, overset digt og et sent trykt manuskript til "Højde- og Vendepunktet" i fremstillingen af hans gerning (jf. citatet ovenfor fra s. 174). Hans indledende opfattelse af Grundtvig som en "avlende Aand" gør netop den individuelle, psykologiske proces til det centrale. Kulminationen er her et upubliceret digt.

Efter at fremstillingen er ført frem til 1824, slipper Vilhelm Andersen eksplicit den biografiske tråd og lader den afløse af en fremstilling af det mangfoldige virke, den vundne klarhed førte med sig, dels i kirken, dels i skolen, eller under ét: i folket (jf. det lange citat ovenfor fra s. 174).

Formentlig medbestemt af den givne ramme træder gennembruddets biografiske grundfigur endnu tydeligere frem i den Grundtvig-artikel, Vilhelm Andersen skrev til anden udgave af Dansk biografisk

148, med facsimile efter s. 540, hvoraf det fremgår, at det er fundet ved prædikener fra 1823-25, jf. Skautrup 1956. Digtet anføres Rønning, bind 3,1 (1911), 42. If. Lundgreen-Nielsen 1980, 928 (note 5) er det senere dateret af Kaj Thaning til første uge af februar 1824, derpå af Thodberg til juni 1824 og på ny af Thaning til umiddelbart efter 10.7.1825. Ifølge K. E. Bugge (i Dansk Biografisk Leksikon, 3. udg.) skete der en teologisk nyorientering advent 1823 ff. og et poetisk gennembrud i januar-februar 1824, sluttende med salmen "Velkommen igen, Guds Engle smaa" sidst på året.

10 Den sene receptionshistorie er et relativt uproblematisk forhold, så længe man opererer inden for en indre udviklings horisont. Problemerne indfinder sig først, når "De Levendes Land" figurerer som belæg eller argument $\mathrm{i}$ historiske virkningssammenhænge, hvor denne første version af digtet aldrig har været kendt. 
Leksikon (Andersen 1936). Skønt det biografiske portræt naturligvis bygger på den forudgående læsning af forfatterskabet i Illustreret dansk Litteraturhistorie (der i forkortet form er gentaget i Det danske Folks Historie, bind 6, 1928, og i Schultz Danmarkshistorie, bind 4, 1942), er det i endnu højere grad styret og struktureret af rækken af oplevelser i Grundtvigs liv. Det er en biografisk systematiseret læsning, der tendentielt trækker Grundtvig $u d$ af litterær, historisk, samfundsmæssig og kirkelig kontekst for i stedet at fokusere på det temperament, der ses som enheden i eller grundformlen bag hans produktion. De æstetiske overvejelser og detail-forbehold, der spillede så væsentlig en rolle for de litteraturhistoriske behandlinger hos Frederik Winkel Horn og Peter Hansen, er nu helt fraværende. Ny er den eksplicitte bestemmelse af Grundtvigs "manio-depressive Temperament" og af hans åndskraft som "den af Sygdommen nærede og æggede produktive Energi" (Andersen 1936, 365). Liberaliteten i både de æstetiske og de individualpsykologiske vurderinger af Grundtvig var i de mellemliggende 15 år blevet større og rummeligere. Holger Begtrups ældre fremstillinger suppleres her af henvisninger til psykiateren Hjalmar Helwegs bog om N. F. S. Grundtvigs Sindssygdom (1918; 2. udg. 1932) og religionshistorikeren Edvard Lehmanns monografi Grundtvig (1929), som ligger bag den psykologiske karakteristik.

Ekskurs: For Vilhelm Andersen har den centrale placering af NyaarsMorgen tidligt ligget fast. I 1912 udgav han en lille bog om litteraturstudiets metoder: Dansk Litteratur. Forskning og Undervisning, som helt frem til den engelsk-amerikanske New Criticism's gennembrud i 1950'erne og 1960'erne forblev fagets grundlæggende lærebog i metodik; endnu i 1970 kunne den genudgives som uglebog. Bogen indeholdt imidlertid også et program for litteraturundervisningen på universiteter og gymnasier. I universitetsregi skelnes der mellem tre slags litteraturlæsning: Klassisk, cyklisk og typisk læsning. Til den første slags hører værker af højeste kunstneriske og historiske betydning, til den anden betydelige værker, som emnemæssigt hører sammen, og til den tredje værker, som er tidstypiske, for eksempel Nyaars-Morgen.

De tidstypiske værker illustrerer faserne i det historiske forløb, her romantikken eller det 19. århundredes "folkelige og kristelige Renæssance", hvor Oehlenschlägers "Thors Rejse til Jotunheim" (i Nordiske Digte, 1807) figurerer som første værk, Nyaars-Morgen som andet:

Her er (...) Livsfornyelse[n] fremstillet lyrisk, uden objektiv Mytologi, som en personlig Myte af Digterens egen Udvikling. Som Følge af 
dette Digts særegne Stilling som Hængselet i Grundtvigs personlige og litterære Udvikling, med Tilbageblik paa hans tidligere Bane og dunkle Fremsyn mod den nye, duer det bedre end noget andet til at oplyse Forskellen mellem hans "Romantik", ("Troen paa at man ved at fordybe sig kunstnerisk eller videnskabeligt i Oldtiden kunde og skulde genføde dens Glans") og hans "Realisme": den gennem det levende Ord foregaaende praktiske "Oplivelse af Nordens Helteaand til kristelige Bedrifter paa en med Tidens Tarv og Vilkaar passende Bane" (Andersen 1912, 117-118).

Det tredje værk er B. S. Ingemanns romancecyklus "Holger Danske" fra 1836.

I Vilhelm Andersens læseplan for gymnasiet indgår Grundtvig ikke.

\section{Danmarks Digtere (Hans Brix)}

Vilhelm Andersens fremstilling var i høj grad indholdsorienteret, men at æstetiske forbehold og smagsdomme ikke restløst havde forladt den akademiske kritik, fremgik endnu i 1925 af kapitlet om Grundtvig i Danmarks Digtere. Fyrretyve Kapitler af dansk Digtekunsts Historie med Billeder (1925). Forfatteren, Hans Brix (1870-1961), der 1919-40 var docent og professor i nordisk litteratur ved Københavns Universitet, fremhævede her Nyaars-Morgen som "det store, dunkle og pragtfulde Levnedsdigt" og roste strofeformen, for her "viser han for en Gangs Skyld ogsaa teknisk Mesterskab (...) Det er ikke Grundtvigs sædvanlige Slaabrokkevers paa syv Linjer, men en Strofe, der kan lade sig se og høre" (181). Om Sang-Vaerk hedder det:

Det sproglige Udtryk har en prydløs, kraftig, stundom stærkt sammenstykket Form. Der lægges ikke Vægt paa Vellyd eller Finhed; snarere ynder Grundtvig at gøre sig noget grov og hverdags i Munden. Hans Billedsprog er overmaade fast formuleret og simpelt. (...) Hans Fejlbetoninger af Ord er talrige og udfordrende, og ligesaa hans meget brede Sprogformer og Rimformer. I øvrigt er hans Teknik proper og haandfast som Kingos (Brix 1925, 185).

Og om sangen om Samson og Dalila (Sang-Veerk nr. $43=$ II, 148-52) hævdes det, at den er "En Smagsforvildelse om ellers nogen (...) Dette er uden Sidestykke i vor Salmedigtning, der dog har oplevet adskilligt rystende" (Brix 1925, 185-186).

Brix' værk var netop "Kapitler af dansk Digtekunsts Historie" (titlen var inspireret af historikeren A. D. Jørgensens Fyrretyve Fortcellinger af Fadrelandets Historie, 1882), små portrætterende afsnit, der hverken indgik i en større historisk helhed, endsige konstruktion eller prætenderede systematisk analyse af de udvalgte 
forfatterskaber. Den impressionistiske, til tider velslebne form gav netop plads for æstetiske domme som de citerede.

\section{Danmarks Digtekunst (F. J. Billeskov Jansen)}

F. J. Billeskov Jansen (1907-2002, professor ved Københavns Universitet 1941-77) var eneforfatter til den genreorienterede litteraturhistorie Danmarks Digtekunst, der udkom med tre bind 1944-58, men aldrig blev afsluttet med det planlagte fjerde bind. Grundtvigs forfatterskab behandles i bind 3, der har perioden ca. 1800-1870 som emne. Koncentreret om den samtidige situation og karakteriseret ved en stram og iøjnefaldende genremassig ordning af stoffet, er fremstillingen bygget strengt kronologisk op, så de enkelte forfatterskaber behandles flere steder, Grundtvigs endda særdeles mange. ${ }^{11}$

I endnu højere grad end hos Vilhelm Andersen indtager det rent litterære stof dermed fremstillingens centrum, mens for eksempel biografiske forhold og kirke- og skolepolitiske perspektiver kun figurerer perifert. Og i endnu ringere grad end hos Vilhelm Andersen gør æstetiske forbehold sig gældende over for den litteratur, der dermed bliver tilbage. Tværtimod: "Der er en egen storladen Hygge over Grundtvigs poetiske Forestillinger om Guds Bolig", siges det med en positiv drejning (Billeskov Jansen 1964, 160), der også får den mere principielle formulering, at styrken i mange af Grundtvigs salmer efter 1837 netop er "denne Forening af det jævne og det sublime" (Billeskov Jansen 1964, 358). En religionshistorisk variant af forholdet dukker op i forbindelse med "Christ stod op af Døde" (1845; SangVaerk nr. 122 = IV, 153-54 / DDS 218), der bygger på flere ældre forlæg, og som Grundtvig bearbejdede i flere omgange: "Denne frie Samvirken mellem byzantinsk og dansk Paasketradition viser Grundtvig som den store lyriske Formidler, den alkristelige Salmedigter" (Billeskov Jansen 1964, 357).

Billeskov Jansen fremhæver, hvordan Grundtvig i "Som Hønen klukker mindelig" (1836; Sang-Vark nr. 58 = I, 147-48 / DDS 409) ser Herren i billedet af en kaldende og værnende høne. Eksemplet trækker imidlertid et par karakteristiske, metodiske forhold med sig: Dels oplyses den nytestamentlige kilde bag billedet (Matt 23,37), dels rubriceres teksten genremcessigt som "en lille kristelig Idyl, en Fabelsalme, som maa minde os om at Kaalunds Fabler for Børn kom snart, i 1845" - i øvrigt med et helt tilsvarende billede (Billeskov Jansen 1964, 357-358).

Det følgende lange citat drejer sig om salmen "At sige Verden ret Farvel" (1843; Sang-Vark nr. 279 = III, 532-33 / DDS 538), hvis helt

11 Om baggrund for og anlæg i Danmarks Digtekunst se nu Conrad 2009. 
umiddelbare afsæt er Oehlenschlägers "Lær mig, o Skov! at visne glad" fra 1813 (DDS 537), som Grundtvig selv havde medtaget i Kirke-Psalmer udgivne til Prøve, 1845, samtidig med, at han til samme melodi havde digtet et modstykke. Til denne tilblivelseshistorie eller genese føjer Billeskov Jansen så - som det fremgår af citatet - en kobling mellem først en idehistorisk og en individualpsykologisk baggrund og dernæst en overraskende motiv- og periodekarakteriserende gruppering af litteratursociologisk tilsnit, efterfulgt af en stilbestemmelse:

I Grundtvigs Strofer ser vi det betrængte Menneske revet ud af sin romantisk vage Samfølelse med Alnaturen og placeret i sin Samhørighed med Jesus Kristus. I Romantikkens Dage sværmede ogsaa den religiøse Følelse, løb med Naturfølelsen og Elskovsfølelsen som Floder ud i Længslernes store Hav. Men efterhaanden kanaliseredes Følelseslivet igen; den religiøse Ubestemthed afløstes af en kristelig Forankring. I Poesiens Plan betød dette, at en ny konfessionsbunden Salme var mulig, hvis Talentet var for Haanden. To af Romantikkens Digtere, som gjorde Bevægelsen med ind i den fornyede Kristendom, blev først med denne Lyrikere i eminent Forstand. Det er da mærkeligt at konstatere, at baade Grundtvigs Salmer og Ingemanns Morgen- og Aftensange kunstnerisk er i Pagt med den nye poetiske Smag for Virkelighedens smaa Træk. Ingemanns Lilleverden af Børn og Blomster og Fugle og Snegle, over hvilken Lysets Engel og den gode Gud vaager, var i Forbund med Chr. Winthers Træsnit og H. C. Andersens Eventyr, og som Paludan-Müller i "Adam Homo" forbinder Grundtvig Hverdagens lille Detalje og Ideens Evighed. Som Salmedigter kan Grundtvig tale jævnt om alt det høje. Hans Tone er festlig som et Orgelbrus, men hans Skildringer er intime og hverdagslige. Medens Ingemann lod Gud aande paa Øjet naar det græder, bragte Vorherre ned paa Jorden, førte Grundtvig desuden vort jordiske Liv, forklaret, op i Himlen (Billeskov Jansen 1964, 346-347).

Det sidste forhold dokumenteres ved, at Billeskov Jansen citerer yderligere to strofer (6 og 8) fra "At sige Verden ret Farvel". Den litteraturhistoriske udredning făr herigennem et tekstanalytisk supplement, idet karakteriserende struktur- og retningsforhold inddrages.

Vilhelm Andersens eksempler og sammenstillinger bliver hos Billeskov Jansen til mere systematisk udfoldede, tekstanalytiske nedslag, der understøttes af komparative greb eller belyses gennem stadier af tilblivelsen: Vilhelm Andersens skoledannende sammenligning med Kingo udbygges i forbindelse med analysen af "De levendes Land". Gendigtning er for Grundtvig ingen hæmsko, tværtimod er den som regel både igangsættende og selvstændiggørende. Et andet metodisk træk, der her kobles med det komparative, er en filologisk baseret 
dokumentation af genetiske forløb med udpegning af for eksempel et forlæg og stadierne i dets videre bearbejdning. Endelig videreføres et receptionshistorisk træk, som allerede var fremme hos Vilhelm Andersen, nemlig de skiftende salmebøgers optagelse og bearbejdning af de grundtvigske salmer.

Bag Billeskov Jansens Grundtvig-afsnit ligger først og fremmest en systematisk litteraturmetodisk skoling og vilje. Dernæst en inspiration fra den akademiske behandling af forfatterskabet, der satte ind $\mathrm{i}$ efterkrigstiden og blandt andet blev ansporet gennem etableringen af Grundtvig-Selskabet i september 1947. Fremhævelsen af forfatterskabets universalromantiske træk, der danner udgangspunkt for den litteraturhistoriske placering, kan formentlig føres tilbage til idehistoriske undersøgelser som C. I. Scharlings monografi og Henning Høirups disputats fra henholdsvis 1947 og 1949, mens motivanalyserne har rod i Helge Toldbergs tilsvarende grundige undersøgelse af Grundtvigs Symbolverden, 1950. Toldbergs resultater bidrager, sammen med Magnus Stevns' efterladte artikler Fra Grundtvigs Salmevcerksted, 1950, til de genetiske træk i Billeskov Jansens fremstilling. Af tilføjelserne til andenudgaven af Danmarks Digtekunst fra 1964 (bind 3, 433) fremgår det, at Billeskov Jansen i særlig grad har haft sin opmærksomhed rettet mod og hurtigt har set pointen i Jørgen Elbeks behandling af de antikke forlæg i Grundtvig og de groeske salmer, 1960.

Opregning af den sekundærlitteratur, den flittige Billeskov Jansen formentlig har støttet sig til og lært af, skal imidlertid ikke dække for, at hans fremstilling overordnet set er styret af de ideer om motiv og motivrealisation, han havde fremlagt i sin Poetik, hvis to små bind udkom i henholdsvis 1940 og 1942. I virkeligheden kan Danmarks Digtekunst ses som en lidt forskudt realisation af en tredje del af poetikken, der efter planen skulle dreje sig om de litterære genrers æstetik. Danmarks Digtekunst skulle ikke fremstå som en litteraturhistorie i traditionel forstand, men have et mere generelt, æstetisk sigte.

Vilhelm Andersens fremstilling havde tilvalgt den litterære del af det mangfoldige forfatterskab og lagt sit snit $1824 \mathrm{og}$ dermed holdt forfatterskabets øvrige dele og ikke mindst dets kirkelige og folkelige virkningshistorie i baggrunden, uden dog at negligere den; samtidig havde han med sin biografiske og litterære fortolkningsramme og åndshistoriske perspektivering givet forfatterskabet en menneskelig forankring og forklaring og dermed en stærk indre sammenhæng uden dog at slippe dets nationalhistoriske betydning. Hos Billeskov Jansen fokuseres der i endnu højere grad på litteraturen. De litterære produkters kontekst er anden litteratur: Den ældre, der har påvirket 
dem, og den samtidige, hvormed de har fælles vilkår og træk. Den litterære produktion bliver en del af det litterære system og af en litterær situation og iagttages under disse betingelsers funktionsperspektiv. Det kan opløse det forfatterskabsmæssige centralperspektiv, der behersker og rettes som forventning til de fleste litteraturhistorier. Opløsning i akademisk analyse, uoverskuelighed og atomisering var da også nogle af de kritikpunkter, der blev fremført i anledning af Danmarks Digtekunst.

En genrebaseret fremstilling som Billeskov Jansens kan imidlertid også være øjenåbnende, fordi den historiserer og relativerer den tidløse, kanoniske status, som for eksempel salmer bibringes i den teologiske brugssammenhæng, der er bestemt af kirkeårets og salmebogens faste systematik. Den kan fungere som en pædagogisk Verfremdungs-teknik, der fører til mange overraskende pointer, ikke mindst $i$ et tilfælde som Grundtvigs.

\section{Politikens Dansk litteratur historie (Gustav Albeck)}

Forlaget Politikens litteraturhistorie er dansk litteraturhistorieskrivnings største salgssucces med et oplag på 70.000 eksemplarer. Bind 2 udkom i 1965. Afsnittet om Grundtvig (116-171) var skrevet af Gustav Albeck (1906-95), der 1956-76 var professor i nordisk litteratur ved Aarhus Universitet. ${ }^{12}$

Fremstillingen falder $\mathrm{i}$ ét samlet, stort afsnit og vender for så vidt tilbage til Vilhelm Andersens monolitiske form, dog nu med mange pædagogiske deloverskrifter. Som hos Billeskov Jansen lægges der vægt på den idehistoriske baggrund, men rammen, der integrerer de udførlige oplysninger, er biografisk fortællende og uden brud på det kronologiske forløb. Imidlertid er sammenbindingen af biografiske greb og litterær produktion ikke så stærk og pointestyret som hos Vilhelm Andersen, mens den litterære kontekstualisering, der - som noget nyt - styrede Danmarks Digtekunst, dog heller ikke er nærværende. Det betyder, at næsten alle dele af forfatterskabet tilgodeses, hyppigst i form af referat og citat, men uden nærmere analytiske eller synkrone tiltag. Lidt groft taget er det en fremstilling, der nævner alt og intet behandler.

Mest detaljeret er gennemgangen af "den mageløse opdagelse" (trosbekendelsen), udfoldet i Kirkens Gienmaele (1825) som et polemisk indlæg mod den unge teolog H. N. Clausen. Gustav Albeck markerer den lille pjece som "et skelsættende værk i den nordiske

12 En ny og udvidet udgave i seks bind udkom 1976-77, dog uden at det berørte Grundtvig-afsnittets tekst i bind 2, 500-553. 
kirke- og åndshistorie. Og i Grundtvigs liv" (Albeck 1965, 154). Gennemgangen følges op af et referat af Grundtvigs fornyede beskæftigelse med nordisk mytologi (her støttet til Kaj Thanings disputats Menneske først - Grundtvigs opgør med sig selv, 1963), hvor forholdet mellem menneskeliv og kristendom afklaredes.

Grundtvigs salmer făr en forholdsvis fyldig, men alligevel blot refererende behandling:

Ved sin brug af originalteksterne forholder Grundtvig sig ofte frit eller reagerer bevidst negativt over for dem, men hvor han er bedst, lader han sig inspirere til en gendigtning, der forener tydelige mærker af hans egen originalitet med et lige så udtalt præg af forlæggets ejendommelighed (Albeck 1965, 161).

En tilsvarende fyldig behandling opnår Grundtvigs verdslige lyrik. Fremstillingen afsluttes (med henvisning til Elbek 1964) med en fremhævelse af, at først modernister som Paul la Cour har peget på rent digteriske kvaliteter ved et kvad som Nyaars-Morgen. Her må det være tilladt at minde om, at det store digt, betragtet som litteratur og som personlig myte, allerede blev fremhævet hos Vilhelm Andersen.

Det er et fællestræk hos Billeskov Jansen og Albeck, at fremstillingen af forfatterskabets bredere virkningshistorie stærkt reduceres, så teologi og livsanskuelse, højskole og politik stort set glider ud, mens den litterære, norrøne baggrund fastholdes. Gustav Albecks egen sammenfatning viser på godt og ondt det mangesidede, men også uprofilerede billede af forfatterskabet:

Grundtvigs mangesidige virksomhed kan ikke splittes op i forskellige dele: præst, historiker, sprogmand, pædagog osv. Alt hænger nøje sammen med hans særegne digteriske begavelse. Som digter hørte han til den visionære type, ikke blot ved den hang til at fremsætte profetier, der var så udtalt $i$ hans ungdom og tidlige manddom, men ved sin forkærlighed for billedsprog og billedtale. Sit særpræg som digter har han netop i dette: at han er seer og udtrykker sig bedst og naturligst, men ikke klarest, i symboler. Her hentede han i sin ungdom en uudtømmelig kilde til et nordisk billedsprog af de norrøne billeder. I de perioder af hans liv, hvor hans grebethed af den lutherske kristendom anfægtede hans udfoldelse som verdslig poet, var det bibelske billedsprog dominerende hos ham, men da han fandt sig selv gennem en afbalancering af det menneskelige og det kristelige, kom det norrøne billedsprog, anvendt med hele hans rige associationsevne, til fuld udfoldelse $\mathrm{i}$ hans verdslige såvel som $\mathrm{i}$ hans religiøse digtning (Albeck 1965, 170). 


\section{Dansk litteraturhistorie (Martin Zerlang)}

Dansk litteraturhistorie bind 1-9 (1983-85) var et kollektivt projekt med i alt ca. 50 forfattere. Værket blev lanceret med et forlagsprospekt, der indeholdt en principiel redegørelse, forfattet af Johan Fjord Jensen, der var projektets nøglefigur. ${ }^{13}$ Her kunne man læse, at fremstillingen ikke var bygget op, så de enkelte forfatterskaber fulgte som "perler på en snor", men i stedet blev set i samspil med de klassemæssige, politiske og sociale sammenhænge, de indgik i. I bind 5, om perioden 1807-48, skrev Martin Zerlang (f. 1952, ansat ved Københavns Universitet) det store afsnit om Grundtvig (62-91). Det indfrier de nævnte træk, for så vidt som fremstillingen er bygget op omkring en række nøglesituationer i Grundtvigs liv, der hele tiden søges reflekteret $i$ et socialhistorisk perspektiv. Afsnittet suppleres af et afsnit $i$ bind 6 om grundtvigianismen.

Dermed har fremstillingen fået træk, der kan sættes i relation til fremstillingerne hos såvel Vilhelm Andersen som Billeskov Jansen.

De udvalgte situationer svarer stort set til de år og 'gennembrud', Vilhelm Andersens fremstilling var bygget op omkring, og rokker for så vidt ikke ved det etablerede og biografisk funderede billede af forfatterskabet og dets forløb: 1801 (rationalisten), 1806 (romantikeren), 1810 (den religiøse krise), 1815 (historieskriveren), 1824 (den mageløse opdagelse), 1832 (menneske først). Nyt er det derimod, at omdrejningspunkterne ikke fortolkes $\mathrm{i}$ et biografisk eller teologisk mønster, men forsøges set som situationer, der kan reflekteres socialhistorisk og med Grundtvigs ambivalente forhold til enevælden som et gennemgående træk. Vendes situationerne alligevel ind mod Grundtvig selv, leder de frem til et billede af ham som en splittet personlighed, der bearbejdede sin omverden i overskuelige modsætningspar, herunder kønsforholdet, som "det prisme, hvorigennem Grundtvig tolkede tilværelsen" (Zerlang 1984, 70).

Heller ikke Billeskov Jansen inddrog en biografisk fortolkning og lod for så vidt nøgleårene figurere med mindre tyngde; blev de inddraget, skete det $\mathrm{i}$ et kronologisk løsere, genrehistorisk perspektiv.

Martin Zerlangs Grundtvig-fremstilling skiller sig imidlertid ud fra så mange andre forfatterskabsbehandlinger i Dansk litteraturhistorie ved at være samlet i ét afsnit. Det gennemgående forhold er groft taget ellers det, at de forskellige dele af et forfatterskab behandles i de sammenhænge, hvori de ifølge fremstillingens tematiseringer hører til, svarende til hvad der var tilfældet allerede hos Peter Hansen (perioden) og senere hos Billeskov Jansen (genren). Zerlangs atypiske Grundtvig-

13 Prospektet, der var udformet som et hefte i værkets format, er aldrig optrykt og har ingen publikationsmæssig status. 
afsnit ligner ved sin sluttede karakter og ikke helt gennemreflekterede binding til den biografisk genererede række af nøgleår Vilhelm Andersens ikke så lidt. Som den store forgængers er afsnittet ganske indforstået skrevet, ikke mindst hvad angår de løbende værkkarakteristikker.

Den litterære kanonisering af salmerne fortsættes. Mens NyaarsMorgen ikke spillede nogen væsentlig rolle hos Billeskov Jansen, gav Albeck det en løfterig omtale. Hos Zerlang får digtet den fyldigste gennemgang i nogen litteraturhistorie, blandt andet med en redegørelse for den spændingsfyldte, til dels symmetriske komposition, og med fremhævelse af den uforløste balance mellem subjektivt og objektivt. Digtets billedfantasier, hedder det, "foregriber surrealismen og kan lede tanken hen på den magiske realisme hos moderne latinamerikanske forfattere" (Zerlang 1984, 78).

\section{Hovedsporet (Johnny Kondrup)}

Hovedsporet. Dansk litteraturs historie, 2005, redigeret af Jens Anker Jørgensen og Knud Wentzel, er en litteraturhistorie i ét bind, skrevet til bachelor-niveauet på universiteternes dansk-uddannelser og derfor koncentreret om det historisk repræsentative. Perioden fra 1800 til 1918 er beskrevet af Johnny Kondrup (f. 1955, ansat ved Københavns Universitet). Her behandles Grundtvig på ca. 41/2 side. Udgangspunktet for fremstillingen er erfaringen på Egeløkke, som tændte gennembruddets ild, mens gennembruddets brændstof var læsningen af romantisk litteratur og filosofi. Efter den religiøse krise i 1810/11 sprængtes syntesen af tysk romantisk tænkning og nordisk mytologi til (midlertidig) fordel for en luthersk kristendom, som - hedder det Grundtvig "søgte tilflugt i".

Nyaars-Morgen, forfatterskabets ene højdepunkt, læses - inspireret af blandt andet Aage Henriksen 1984 - som en refleks af Grundtvigs eget livsløb og som et udtryk for hans stærke vilje til selvfortolkning og sammenhængende forståelse. Værkets sene receptionshistorie trækkes frem, ligesom den grundtvigske virkningshistorie i dansk kultur summarisk bliver det.

Det andet højdepunkt i det litterære forfatterskab udgøres af salmerne.

I den sammenfattende vurdering hedder det:

Overhovedet blev det Grundtvigs skæbne på godt og ondt at ende som institution. Det var efter hans eget ønske (...). Men det betød også, at han gav afkald på i hvert fald at formulere nogle af de kriseerfaringer, som bar hans tidlige forfatterskab, og som altid havde åbnet for nye, grænsesprængende indsigter (Kondrup 2005, 318-19). 
Uden helt at være udeladt er det øvrige stof i Kondrups fremstilling trængt sammen, så de to højdepunkter får den størst mulige plads og tyngde. Den eksplicitte (modernistiske?) vurdering er, at i hvert fald det ene af dem, Nyaars-Morgen, blev båret af en evne til at formulere kriseerfaring og sprænge forståelsesmæssige grænser, som Grundtvig senere afstod fra at gøre brug af. Det er en vurdering, som synes at ligge specielt Jørgen Elbeks nær, ikke blot hvad angår hans Grundtvigartikler om Nyaars-Morgen, men også hans syn på den unge Johannes V. Jensen og hans bevidsthed om "den reduktion, der skulle komme, fra sublim nihilisme til positivitet af lavere orden". ${ }^{14}$

Som det vil være fremgået, er synspunktet i virkeligheden ikke langt fra, hvad der lå implicit $\mathrm{i}$ Vilhelm Andersens fremstilling.

\section{Dansk litteraturs historie (Sune Auken)}

Den seneste store, danske litteraturhistorie er Dansk litteraturs historie 1-5 (2006-08), redigeret af Klaus P. Mortensen og May Schack. Her har Sune Auken (f. 1970, ansat ved Københavns Universitet) i bind 2, der omfatter perioden 1800-1870, skrevet blandt andet afsnittet om Grundtvig, i alt 39 sider, inklusive en del store illustrationer. Til hans bagage hører blandt andet disputatsen Sagas spejl fra 2005.

Sune Aukens fremstilling er kronologisk ordnet, med udviklingen af Grundtvigs billed- og symbolsprog, også kaldet "poetisk grammatik", som den røde tråd (Auken 2008, 213), mens et biografisk tolkende perspektiv er langt mindre fremtrædende end hos så forskellige forgængere som Andersen og Zerlang. Inspiration fra Helge Toldbergs disputats, der i sin kortlægning af symboler og motiver søgte på tværs af teksterne og dermed ind mod selve den digteriske evne, synes således iøjnefaldende. Fra det romantiske og mytologiske udgangspunkt følges udviklingen eller ændringerne (det mindre psykologiserende udtryk 'omslag' benyttes flere gange): Omkring 1815 registreres tilstedeværelsen af to stilbestræbelser, dels et drillende, ofte grovkornet vid, dels en visionær stil, der er rig på billeder og associationer. Især den visionære stil bringes til fuld udfoldelse i Nyaars-Morgen, der sammen med salmerne udpeges som den kvalitative kerne i Grundtvigs litterære produktion.

Et hovedanliggende i Nyaars-Morgen er, hævdes det, den eksistentielle spænding mellem en erkendelse af foreløbigheden som menneskeligt grundvilkår og de selvbiografisk baserede beskrivelser af gennembrud af en næsten absolut karakter. Spændingen spejles i Grundtvigs mange overvejelser over forholdet mellem mytologi, historie og kristendom og udfoldes gennem et personligt reflekteret 
billedsprog, der er rigt på udtryk for modsætningen mellem lys og mørke, dag og nat, varme og kulde og døgnets og årstidernes stadige vekslen.

Den rige salmeproduktion i sidste del af 1830'erne beskrives i en klar og overskuelig form og med fremhævelse af, at Grundtvigs billedverden rettes ind efter den kirkelige brugssammenhæng - uden dog af den grund at blive billedsvag eller abstrakt.

\section{Litteraturhistoriografisk status}

At samle de litteraturhistoriografiske tråde er langtfra så enkelt som at betragte de danske litteraturhistorier enkeltvis. Her skal det forsøges i to træk, hvoraf det første, der drejer sig om en række indbyrdes forbundne fravalg og munder ud i et spørgsmål om reprcesentativitet, er det mest sammensatte, mens det andet, der drejer sig om tilvalget af kanoniske tekster, er enklere at håndtere.

De litteraturhistoriske behandlinger af Grundtvig kan beskrives som fravalg, der indbyrdes er forbundet med hinanden i et komplekst og til dels selvforstærkende mønster.

Det første fravalg er et fravalg af det ikke-digteriske forfatterskab og efterhånden også dettes virkningshistorie og de respektive teologiske, historiske og mytologiske udlægninger, der i stigende grad alene bliver et anliggende for adepter og specialister. Inden for det analyserede materiale er Harald Høffdings kontante afskrivning af Grundtvig som videnskabsmand et tidligt eksempel på denne udvikling.

Fravalget af i litteraturhistorisk sammenhæng at fremstille det ikke-digteriske forfatterskab og dets tekstlige virkningshistorie (grundtvigianismen) forstærkes formentlig i takt med, at denne virkningshistories indirekte, praktiske gennemslag inden for kirke, højskole og andelsbevægelse efterhånden tager af og smelter sammen med andre traditioner.

Hos Vilhelm Andersen formuleres fravalget i en forskudt form som et positivt tilvalg. Det synspunkt, at det er i litteraturen, man finder den "rigtige" Grundtvig, og det biografiske greb at gøre en udviklingspsykologisk sammenkædning af rækken af "oplevelser" eller "gennembrud" til det centrale og sammenhængsskabende i forståelsen af forfatterskabet var metodiske træk, der gjorde to fravalg eller reduktioner mulige: Dels at forholde sig til forfatterskabet uden om den grundtvigianske tradition i bredeste forstand, dels at nedtone (ikke eliminere) det ikke-digteriske forfatterskab til en beskrivelse af dets funktion og virkning. 
At der hos Vilhelm Andersen er tale om fravalg, camoufleres eller overskygges af tilvalgets attraktioner: Blotlægningen af digtningens kunstnerisk kvalificerede og hidtil upåagtede tekster - og en dybtgående, biografisk forklaring, byggende på en psykologisk forståelse af forfatterskabets produktive energi.

Efter mit skøn kan indflydelsen fra Vilhelm Andersens Grundtvigkapitel næppe overvurderes. Hans littercere tilgang til forfatterskabet og de heraf afledte vurderinger er $\mathrm{i}$ alt væsentligt blevet bekræftet $\mathrm{i}$ dansk litteraturhistorieskrivning. Hertil kommer, at de teologiske læsninger af de litterære tekster, der har været bragt på bane, men ikke de litterære alene, udfolder sig inden for de rammer og præmisser, han har lagt ud. Det er, grundlæggende set, først og fremmest ad den vej, der stadig bliver hentet nye resultater frem.

Et særligt forhold gør sig i forbindelse med fravalget gældende omkring Grundtvigs salmer. Som vist pegede Vilhelm Andersen på de litterære tekster Nyaars-Morgen og "De Levendes Land" som højdepunkter i Grundtvigs forfatterskab. Men samtidig var hans gennemgang af salmerne både fyldig og pointerig, med gode eksempler på deres sproglige rigdom, billeddannelse og komposition. Med den fine, pædagogiske sammenstilling med Kingo skabte han en virkningsfuld, litteraturhistoriografisk topos.

Med et par karakteristiske formuleringer trak han samtidig diskret en streg i det konfinium mellem religiøs digtning og teologi, som hans litteraturhistoriske fremstilling her befandt sig i. Fra den ene (teologiske) side hedder det, at "I hans danske Menighed traadte Salmen i Dogmatikens Sted" (Andersen 1924, 181), fra den anden (litterære, inkl. alment-religiøse) side blev salmerne set som udstrålinger af "det religiøse Digt 'De Levendes Land', der er Kernen i al hans Digtning" (186).

Det forhold, at salmerne kan betragtes og analyseres som litteratur, men i sidste instans føjer sig ind under teologisk dogmatik og dermed rummer en erkendelsesmæssig begrænsning, kan følges som et ambivalent forhold frem til de seneste litteraturhistoriske fremstillinger. Lidt kort sagt drejer det sig om, at litteraturhistorieskrivningen går hånd $\mathrm{i}$ hånd med et modernistisk syn på litteraturen og dens 'udvikling'.

Det andet fravalg finder sted $\mathrm{i}$ forhold til de rammer, forfatterskabet ses under. I indledningen til sit kapitel kunne Vilhelm Andersen skrive: "Men dette Forfatterskab, det maa ogsaa Litteraturhistorien tilstaa, er tillige et Udtryk, vel ikke det klareste, men det kraftigste, for hans Folks og dets Aands Kamp for at blive sig selv bevidst" (Andersen 1924, 141). 
Som udtryk for en åndelig kamp repræsenterer forfatterskabet en større sammenhæng. En grundlæggende figur i al litteraturhistorieskrivning er en opbygning omkring tekster og situationer, der rummer en stærk, eksemplarisk slagkraft, formelt i form af en synekdoke, der i det små lader den store sammenhæng blive synlig. ${ }^{15}$ Og den store sammenhæng er her den danske ånds historie. Skønt Vilhelm Andersen i de enkelte kapitler udnytter en biografisk ramme, får de indvundne delresultater mening eller betydning som repræsentative bidrag til en samlet fremstilling af denne historie. Den retoriske term synekdoke (på latin sub-intellectio) betyder egentlig medforståelse, det vil sige at man, i det man forstår, samtidig under- eller over-forstår noget andet.

Generelt kom dansk litteraturhistorieskrivning i voksende omfang til at fravælge denne bærende historie. Flemming Conrad har (i Conrad 2006) gjort opmærksom på et karakteristisk genremæssigt forhold i denne forbindelse og sammenfattet det på den måde, at der i sidste del af 1800-tallet sker en forskydning fra fagligt akademiske fremstillinger til mere populære, og at vægten dermed også forlægges fra digtning som udtryk for folket til digtning som udtryk for en individuelt skabende personlighed, fra et afsnit i en litteraturhistorie til et forfatterportræt.

Vilhelm Andersen stod med sin egen fremstilling så at sige midt $\mathrm{i}$ vadestedet mellem litteraturhistorie og biografi. Billeskov Jansen reducerede i 1958 det biografiske stof til fordel for en litterær kontekstualisering, der samtidig var ensbetydende med en relativering og en historisering af teksterne. Billeskov Jansen fravalgte ikke blot det ikke-digteriske forfatterskab, men tillige den biografiske forståelsesramme, så forfatterskabet var på vej til at opløses i systematiske genrebestemmelser og æstetiske punktanalyser. Ordet 'betydning', der betegner forbindelsen mellem den enkelte tekst og den overordnede sammenhæng, forekommer yderst sjældent, jævnfør at den litteraturhistoriske periodisering først og fremmest synes at hvile på et filosofisk og idehistorisk grundlag, der kun figurerer i en forholdsvis abstrakt form ved indledningen til hovedkapitlerne. Og det er karakteristisk, at Nyaars-Morgen næsten forbigås: Danmarks Digtekunst savner genre-kategorier for det selvbiografisk-kosmologiske langdigt.

15 Jf. White 1999. Artiklen bar oprindelig den mere rammende titel "The Rhetoric of Interpretation"; i teksten formuleret som et forsøg på at beskrive "something like the plot of all possible emplotments" (White 1999, 144). Thomsen og Larsen 2005 indeholder oversættelse af en række litteraturhistoriografiske bidrag, der yderligere belyser problemstillingen. 
Martin Zerlang søgte at reflektere forfatterskabets mange gennembrud og især brudflader socialhistorisk. Det er brudfladerne, der bliver repræsentative og derfor tillægges betydning. Det er baggrunden for, at væsentlige dele af det øvrige forfatterskab holdes nærværende i fremstillingen, ligesom grundtvigianismen tages op i det følgende af litteraturhistoriens bind. På den baggrund kunne Zerlang give en forholdsvis fyldig, strukturel beskrivelse af Nyaars-Morgen, der i kraft af et modernistisk perspektiv kunne forholde sig positivt til de brudflader, Vilhelm Andersen måtte tage æstetisk forbehold overfor.

Med lidt forskellig vægtning og plads omkring sig følges fokuseringen på det store digt op i Johnny Kondrups og Sune Aukens bidrag, mens resten af forfatterskabet (teologi, historie, mytologi) gradvist taber mere og mere i vægt. Resultatet af den proces ses især i Kondrups nødvendigvis korte kapitel.

\section{Kanonisk og udgivelsesmassigt set}

Den skitserede udvikling betyder, at det bliver en stadigt større udfordring for litteraturhistorieskrivningen, at Grundtvig ikke skrev noget klassisk litterært værk, og den er ensbetydende med, at Grundtvigs forfatterskab ikke indgår $\mathrm{i}$ nogen af de danske ministerielle kanoner med et selvstændigt værk, men alene som bidragyder til grupper af digte, $\mathrm{fx}$ salmer.

For Vilhelm Andersen, der trak Nyaars-Morgen frem og etablerede rammen for at tilskrive digtet betydning, stillede æstetiske forbehold sig i sidste ende i vejen for at løfte det til den højeste status.

Da Georg Christensen i 1941 (sammen med Hal Koch) udgav bind 7 af Grundtvigs Voerker $i$ Udvalg, der blandt andet rummer NyaarsMorgen, beskrev han i sin indledning digtet med en karakteristisk, ambivalent passus: "For os indtager det en central Stilling i Grundtvigs Produktion. Men for dets rent digteriske Værdiers Skyld vilde næppe mange Nutidslæsere søge tilbage til det" (XXVII).

Formuleringen ligger formentlig i forlængelse af Vilhelm Andersens holdning, men med et stærkere forbehold. Det anfægter imidlertid ikke tekstens centrale stilling eller betydning. Men den positive vurderings præmisser er udeladt; de beror på en uudtalt eller ikkeeksisterende ramme.

Et lignende forhold gør sig i virkeligheden gældende i Dansk litteraturs historie. Her er de æstetiske forbehold over for digtet omsider helt væk; den karakteristiske, litterære ambivalens over for salmerne er intakt - og den litteraturhistoriske forklaringsramme, der 
skal bære betydningen, svæver, sådan som det fremgår af følgende citat:

Nyaars-Morgen er Grundtvigs største enkeltstående litterære værk. Salmerne som helhed blev vel hans livsværk som digter, men ingen anden enkelttekst i forfatterskabet er af samme betydning som NyaarsMorgen (Auken 2005, 353).

Er rækken af fremhævelser af Nyaars-Morgen efterhånden lang i de danske litteraturhistorier, så har beskrivelser, karakteristikker og tilløb til fortolkning været påfaldende tøvende og bevidst forsigtige over for den vanskeligt tilgængelige tekst. Men tekstens position understøttes af en række særstudier. Jørgen Elbeks første, grundlæggende bidrag til en helhedslæsning i 1964 er blevet fulgt op af en så lang række af stadige forsøg på litterære læsninger, at man tør hævde, at nyere dansk litteraturforsknings stærkeste og mest komplekse bidrag til den brede og omfangsrige Grundtvig-litteratur er læsningerne af netop NyaarsMorgen. ${ }^{16}$

Nyaars-Morgen (og "De Levendes Land") bliver dermed et godt eksempel på det, som i tysk kanondebat er blevet kaldt en tydningskanon (Deutungskanon, Sinnpflege, jf. Dahl 2002). En tydningskanon fastlægges ikke i en central myndigheds regi, men gør sig decentralt gældende i for eksempel litteraturhistorier, i monografier og i tidsskrifternes litterære afhandlinger: Alle de steder, hvor de enkelte teksters værdi langsomt og omhyggeligt afprøves, i den ene tolkning efter den anden og som led i det stadige traditionseftersyn, der er betinget af historiens (og modernitetens) gang og udviklingen af den litterære metodik.

I 1996 stod en arbejdsgruppe under Det Danske Sprog- og Litteraturselskab for en udredning af behov og problemer i forbindelse med videnskabelig udgivelse af danske litterære tekster efter 1800 (Andersson 1996). Hvad Grundtvig angik, var vurderingen, at de foreliggende, større Grundtvig-udgaver ved Holger Begtrup og ved Georg Christensen og Hal Koch trods deres alder stadig relativt nemt lod sig anskaffe antikvarisk. Selvom de i flere henseender var utidssvarende, så var de dog tilstrækkeligt pålidelige og anvendelige. En nyudgivelse af Grundtvigs forfatterskab ville være særdeles ressourcekrævende. ${ }^{17}$

16 Uden fordring på komplethed kan nævnes: Toldberg 1950; Elbek 1964; Henriksen 1971; Elbek 1973; Behrendt 1974; Borum 1983, 96-123; Henriksen 1984; Christensen 1987, 43-93; Auken 2005, 352-459; Nyegaard 2007.

17 På det punkt stiller sagen sig i dag anderledes, idet en digital tekstkritisk og kommenteret udgave af samtlige Grundtvigs værker nu er iværksat. Den 
På et mindre fordringsfuldt niveau meldte især tre opgaver sig: To bind i serien Danske Klassikere med større udvalg af henholdsvis salmer og verdslige digte. For salmernes vedkommende svarende til seriens bind med Kingos og Brorsons salmer og formentlig med den moderne udgave af Sang-Vaerk som afsæt. For de verdslige digtes vedkommende uden andet umiddelbart arbejdsgrundlag end Svend Grundtvigs gamle udgave af Poetiske Skrifter. De to bind er ikke for øjeblikket optaget i seriens program.

Desuden stod en kritisk og kommenteret udgave af NyaarsMorgen i 1996 på det litterære udgivelsesprogram. Den kunne imidlertid ikke realiseres og er siden taget af programmet. Men som afløser af Holger Begtrups udgave fra 1901 må en tekstkritisk og gennemkommenteret udgave af Nyaars-Morgen - inkl. de ledsagende "Glarøjne" og andet supplerende materiale, samt en grundig indledning eller efterskrift - stadig vurderes som et højt prioriteret litterært ønske.

En moderne, altomfattende digital udgave er (som nævnt i note 17) under forberedelse. Indtil den foreligger, afspejler de udgivelsesmæssige forhold de danske litteraturhistoriers uafklarede forhold til Grundtvigs forfatterskab.

\section{Forkortelser}

DBL: Dansk biografisk Leksikon

DDS03: Den danske salmebog (2003), København.

\section{Litteraturliste}

\section{Voerker af Grundtvig}

Balslev, Th. et al. (udg.) (1944-64), Grundtvigs Sang-Vark. Samlet Udgave, bind 1-6, København.

Begtrup, Holger (udg.) (1901), N. F. S. Grundtvig: Nyårsmorgen, udgivet med Oplysninger, København.

- (udg.) (1906), Nik. Fred. Sev. Grundtvigs Udvalgte Skrifter, bind 4, København.

Christensen, Georg og Hal Koch (udg.) (1941), N. F. S. Grundtvigs Varker $i$ Udvalg, bind 7, København.

Grundtvig, Svend (udg.) (1883), N. F. S. Grundtvigs Poetiske Skrifter, bind 5, København.

forestås af Grundtvig Centeret, der på grundlag af en finanslovsbevilling blev oprettet 1. januar 2009. Udgavens hovedredaktør er Johnny Kondrup. Handlingsplanen rækker foreløbigt frem til 2013. 


\section{Voerker af andre forfattere}

Albeck, Gustav (1965), Dansk Litteratur Historie, bind 2, København, 116171.

- (1987), "Har Grundtvig-Selskabet forsømt Digteren Grundtvig?", Grundtvig-Studier 1987, København, 29-44.

Andersen, Vilhelm (1912), Dansk Litteratur. Forskning og Undervisning, København.

- (1924), Illustreret dansk Litteraturhistorie, bind 3, København, 141-217.

- (1936), "N. F. S. Grundtvig" i Dansk biografisk Leksikon, bind 8, København, 356-379.

- (1985), Om at skrive den danske ånds historie. Ti artikler 1888-1951. Udg. Per Dahl, København.

Andersson, Henrik et al. (1996), Udgivelse af danske littercere tekster efter 1800. En redegørelse for behov, problemer og perspektiver, København (Også på htttp://dsl.dk/litteratur/den-rode-betenkning.pdf.)

Auken, Sune (2005), Sagas spejl. Mytologi, historie og kristendom hos N. F. $S$. Grundtvig, København.

- (2008), Dansk litteraturs historie, bind 2, København, 199-237.

Balling, Jakob L. (1993), "Tradition og modernitet i Nyaars-Morgen" i Dansk Teologisk Tidsskrift, København, 120-132; optrykt i sammes: Historisk Kristendom. Artikler og afhandlinger i udvalg (2003), København, 241252.

Begtrup, Holger (1901), N. F. S. Grundtvigs kirkelige Syn 1825. En historisk Indledning, København.

Behrendt, Poul (1974), Viljens former. Augustin - Goethe - Grundtvig, København.

Billeskov Jansen, F. J. (1964 [1958]), Danmarks Digtekunst. Tredje Bog. Romantik og Romantisme. Anden Udgave, København.

Borum, Poul (1983), Digteren Grundtvig, København.

Borup Jensen, Th. og K. E. Bugge (red.) (1972), Salmen som lovsang og litteratur, bind 1-2, København.

Brix, Hans (1925), Danmarks Digtere. Fyrretyve Kapitler af dansk Digtekunsts Historie, København, 175-190.

Bugge, K. E. (1980), "N. F. S. Grundtvig” i Dansk Biografisk Leksikon, 3. udg., bind 5, København, 318-327.

Christensen, Bent (1987), Fra drøm til program. Menneskelivets og dets verdens plads og betydning $i N$. F. S. Grundtvigs kristendomsforståelse fra Dagningen i 1824 over Opdagelsen i 1825 til Indledningen i 1832, København.

Conrad, Flemming (1996), Smagen og det nationale. Studier $i$ dansk litteraturhistorieskrivning 1800-1861, København.

- (2006), For loeg og laerd. Studier i dansk litteraturhistorieskrivning 1862ca. 1920, København.

- (2009), "Omkring 'Danmarks Digtekunst”" i Danske Studier, København, 106-139. 
Dahl, Per (2002), "Kanon, klassikere og kritiske udgaver" i Lars Burman og Barbro Ståhle Sjönell (red.), Text och tradition. Om textedering och kanonbildning, Stockholm, 77-100.

Elbek, Jørgen (1960), Grundtvig og de grøeske salmer, København.

- (1964), "Nyaars-Morgen" i Grundtvig-Studier 1964, København, 30-46.

- (1966), Johannes V. Jensen, København.

- (1973), Grundtvigs atten prøveår, Grenå.

Hansen, Peter (1886), Illustreret dansk Litteraturhistorie, bind 2, København. Henriksen, Aage (1971), Gotisk tid. Fire littercere afhandlinger, København.

- (1984), "Nyaars-Morgen - vandskellet i Grundtvigs forfatterskab" i Fl.

Ettrup og Johs. H. Christensen (red.), De Levendes Land. Grundtvig 1984, København, 47-58; optrykt i Aage Henriksen: Svanereden. Essays, foredrag, debat (1990), København, 115-133.

Høirup, Henning (1948), Grundtvigs Syn paa Tro og Erkendelse. Modsigelsens Grundsatning som teologisk Aksiom hos Grundtvig, København.

- (1991), Så fjern og dog så næer. Erindringer, København.

Jensen, Johan Fjord (1962), Den ny kritik, København.

Jørgensen, A. D. (1896), "Grundtvigs 'Nyårsmorgen"”, optrykt i sammes Historiske Afhandlinger, bind 3 (1899), København, 432-463.

Jørgensen, Aage (2009), "Finest frugt - om 'den Vartou Kjællingepræst'. En guide til Grundtvig-Studier 1948-2008, I" i Grundtvig-Studier 2009, København, 20-85.

Kondrup, Johnny (2005), Hovedsporet, København, 314-319.

- (2006), "Disputatsforsvar. Anden officielle opposition ved Sune Aukens disputatsforsvar den 3. juni 2005" i Nordica, bind 23, Odense, 211-230.

Ljung, Per Erik (2002), "Litteraturhistoria efter andra världskriget - några tendenser" i Per Dahl og Torill Steinfeld (red.), Videnskab og national opdragelse. Studier $i$ nordisk litteraturhistorieskrivning, del 2, København, 617-705.

Lundgreen-Nielsen, Flemming (1980), Det handlende ord: $N . \quad F . S$. Grundtvigs digtning, litteraturkritik og poetik 1798-1819, København.

Monrad, J. H. (1896), Studier over Grundtvigske Digte, København.

Nyegaard, Marie Louise (2007), "Nyaars-Morgen - historie, fornyelse og fællesskab" i Grundtvig-Studier 2007, København, 258-273.

Pedersen, Kim Arne (2002), "Grundtvig på anklagebænken. En redegørelse for hovedlinjer $\mathrm{i}$ de sidste ti års danske Grundtvig-reception og deres forhold til centrale motiver i Grandtvigs forfatterskab og dets virkningshistorie" i Grundtvig-Studier 2002, København, 184-251.

- (2003), "Den teologiske Grundtvigforskning siden anden verdenskrig" i Hanne Sanders og Ole Vind (red.), Grundtvig - nyckeln till det danska?, Göteborg/Stockholm, 150-179.

Rønning, Frederik (1907-14), N. F. S. Grundtvig. Et bidrag til skildring af dansk åndsliv $i$ det 19. århundrede, bind 1-4, København.

Scharling, C. I. (1947), Grundtvig og Romantiken. Belyst ved Grundtvig Forhold til Schelling, København.

Skautrup, Peter (1956), "De Levendes Land" i Grundtvig-Studier 1956, København, 21-39.

Stevns, Magnus (1950), Fra Grundtvigs Salmevarksted, København. 
Sørensen, Peer E. (2009), "Den nationale litteraturhistories svanesang? Nogle betragtninger i anledning af Dansk litteraturs historie, 1-5 (20062009)", Edda 4, København, 409-430.

Thaning, Kaj (1963), Menneske først - Grundtvigs opgør med sig selv, København.

Thodberg, Christian (1989), "Digtet 'De Levendes Land' belyst ud fra Grundtvigs prædikener og den bibelske poesi" i sammes: Syn og sang. Poesi og teologi hos Grundtvig, 1989, København, 173-209 (opr. trykt 1983).

Thomsen, Mads Rosendahl og Svend Erik Larsen (red.) (2005), Litteraturhistoriografi, Århus.

Toldberg, Helge (1950), Grundtvigs Symbolverden, København.

Undervisningsministeriet (udg.), (1994), Dansk litteraturs kanon. Skønlitteraturen i skolen, København.

White, Hayden (1999), "Narrative, Description, and Tropology in Proust" i sammes, Figural Realism. Studies in the Mimesis Effect, Baltimore, 126146 (opr. Trykt i Poetics Today 9:2 1988).

Winkel Horn, Frederik (1881), Den danske Literaturs Historie, bind 2, København, 189-234.

Zerlang, Martin (1984), Dansk litteraturhistorie, bind 5, København, 62-91. 